\title{
キャノピー内外における都市キャノピーモデルの再現性に関する実験的検討 EXPERIMENTAL STUDY ON THE VALIDITY OF URBAN CANOPY MODEL IN AND ABOVE THE CANOPY LAYER
}

\author{
萩島 理*, 谷本 潤**, 片山忠久*** \\ Aya HAGISHIMA, Jun TANIMOTO and Tadahisa KATAYAMA
}

\begin{abstract}
The Urban Canopy Model that has been widely used as a practical methodology to estimate a friction force generated by a bulk of building roughness, was precisely confirmed from the validation viewpoint. In three series of experiments, both disposition and height of building models were particularly concerned. In short, following three schemes for the models were intrigued;

- Arrayed in both staggered and normal rectangular block consisting of same height models

- Arrayed in both staggered and normal rectangular block consisting of models combined two heights

- Random shaped model derived from a certain real city

With respect to the space-averaged vertical wind profiles, good agreement between the experiments and calculations was obtained in any cases. That led to verify the fact that the Urban Canopy Model was deemed as one of the most effective procedures to predict the wind characteristics in urban canopy layer.
\end{abstract}

\section{Keywords : canopy model, vertical wind profile, wind tunnel experiment キャノピーモデル、風速プロフィル、風洞実験}

\section{1. はじめに}

都市を吹き抜ける風は、自動車排ガス等の污染物質を希釈・昖散寸 るのみならず、高温化しつつある夏季の屋外環境に涼をもたらし、室 内の通風量を増加させるなど、熱環境の面でも様々な効果が期待され る。そのため、近年では、夏季の空調負荷低減や屋外温熱快適性向上 の観点から、都市の風環境については適度な「風通し」を確保するの が望ましいという考え方が一般的になってきている。しかし、建物の 高層化、高密度化が進む現状では、都市の風は年々弱まる傾向にある。

このような背景から、「風通しの良いまちづくり」が地方自治体の工 コシティ構想の一翼として推進されつつある。「風通しの良いまちづ くり」のための都市計画・建築設計の具体的指針を得るためには、複 雑形状の建物群が集積する実在都市の「風通し」の定量的評価、即ち 街区風速の予測が望まれる。建物周辺気流の予測手法として、コンピ ユーターによる乱流数值計算に関する研究は多数行われており 、設 計時の環境アセスメントのツールとしても一般化しつつある ${ }^{2) 。 し か ~}$ し、都市広域を対象として、個々の建物の形状を解像できる細か心格 子分割による乱流数值計算を行う事は、コンピューターの性能が飛躍 的に高まった現在においても莫大な計算負荷を要する。

これに対して、キャノピーモデルは、運動量輸送方程式に粗度体積 密度と抗力項を組み込むことで、複雑形状の市街地における空間平均
風速を粗い差分格子を用いても得ることが出来る手法 ${ }^{344}$ であり、都市 の風通しの有効な評価ツールとして期待される。キャノピーモデル中 に含まれる実験定数であるラフネスパラメーターについは、千鳥配 列の立方体模型群の床面抗力に関する風洞実験 のに基づき、丸山によ り粗度体積密度との関係が明らかにされている。ままたここのラフネ スパラメータを用いたキャノピーモデルの計算結果が市街地形状模型 上空の鉛直風速分布を精度良く予測できる事も確認されている。

诸市の風通し小、即ち夏季の暑熱緩和効果や室内通風量の増加によ る空調時間の短縮効果等の定量的予測を目的としてキャノピーモデル を用いる場合、キャノピー上空のみならず、人間の主たる生活空間で あるキャノピー内、特に地表付近における空間平均風速の予測精度が ある程度保証されている事が望ましい。しかし、キャノピー高さ以下 の空間においては、キャノピーモデルの再現性については十分に検証 されていないのが現状である。

以上の背景から、本稿では、キャノピーモデルを都市の風通し評価 のツールとして位置づけ以下の検討を行う。まず、様々な模型配列に おける風洞実験を行い、模型周辺の3 次元的気流分布の測定值加空 間平均風速の鉛直分布を求める。次に、風洞実験を再現したキャノピ 一モデルによる数值計算を行い、実験值との比較を行う。以上により、 キャノピー内外におけるキャノピーモデルの再現性の確認を行う。特
* 九州大学大学院総合理工学研究院 助手·工修

** 九州大学大学院総合理工学研究院 助教授 ·工博

*** 九州大学大学院総合理工学研究院 教授・工博
Research Assoc., Interdisciplinary Graduate School of Engineering Sciences, Kyushu Univ., M. Eng.

Assoc. Prof., Interdisciplinary Graduate School of Engineering Sciences, Kyushu Univ., Dr. Eng.

Prof., Interdisciplinary Graduate School of Engineering Sciences, Kyushu Univ., Dr. Eng. 
に、キャノピーモデル検証の対象としては、同一サイズ直方体模型の 千鳥配列、整形配列のみならず、実在都市への適用を想定して、高さ の異なる直方体模型が交互に並ぶ場合、実在市街地の縮小模型の場合 についても取り上げる。

\section{2. キャノピーモデルの概要 \\ 2-1 基硓式}

ヴ タン カらによるキャノピーモデルの基礎式8を表 1 に示す注り。 粗度形状を表現するパラメー夕は、粗度表面積密度 $a_{s i}$ と流体体積密度 $G$ のつで、粗度の影響は各輸送方程式中の抗力項 $F_{x i}, F_{k} 、 F_{E}$ により 考慮されている。粗度表面積密度 $a_{x}$ は単位流体体積当たりの粗度表面 積、流体体積密度 $G$ は単位空間体積当たりに流体が占める体積の割合 である。直方体粗度が整然と千鳥または整形に配列されている場合、 粗度表面積密度及び流体体積密度は次式で表される。尚、(11)式中に 含まれる粗度表面積は\{粗度要素の壁面積/4\}で定義され、千鳥配列及 ひ整形配列は同值となる》。

$a_{x i}=\frac{B}{(B+W)^{2}-B^{2}} ; Z<h \ldots(12) \quad G=1-\rho_{r}=1-\frac{B^{2}}{(B+W)^{2}} ; Z<h \ldots(13)$

$B:$ 模型幅, $W$ : 模型間隔， $h$ : 模型の高さ, $\rho_{r}:$ 粗度体積密度

\section{2-2 ラフネスパラメーター}

抗力項中のラフネスパラメーター $C_{f 、} C_{\rho E}$ と粗度体積密度の関係は、 図 1 に示すとおり丸山により実験的に整理されている。。パラメータ 一の同定方法は次の通りである。即ち、千鳥状に配列された同一サイ ズの立方体粗度群の床面抗力に関する風洞模型実験と、2 次元標準 $k$ £モデルに抗力項を組み込んだキャノピーモデルによる数值計算の床 面抗力が最適となる $C_{f 、} C_{\rho:}$ を求める、というものである。

\section{3. 風洞実験およひ乱流数値計算の概要 \\ 3-1 風洞実験装置及乙模型配列状況}

本研究で用いた風洞装置は、全長約 $19.5 \mathrm{~m}$ の回流式境界層風洞であ る。測定洞の寸法は長さ $8 \mathrm{~m}$ 、高さ $1 \mathrm{~m}$ 、幅 $1.5 \mathrm{~m}$ である。実験は 4 夕 イプの模型配列について、計16ケース行っている。実験種别每の模型 配列及び測定点の配圆状況を図 2 に、各実験ケ一スの模型配列の概要 を表 2 に示す。

実験 $A$ は同一サイズの直方体の千鳥配列で、丸山が図 1 のラフネス パラメーターを同定した際の実験条件 クである立方体の千鳥配列に近 い条件である。これに対して、実験 $B$ は同一サイズの直方体模型を整 形配列した条件である。実験 $C$ は高さの異なる 2 種類の直方体（以下、 高い方の模型を高層模型、低い方の模型を低層模型とする）を、 交互に配列している。模型高さの組み合わせが異なる 3 パターン、 整形配列、千鳥配列の 2 通りの、合計 8 ケースについて実験を行

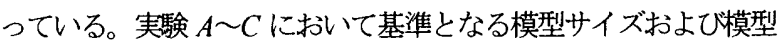
間隔は、代表的な高層・高密市街地としての丸の内および銀座に おける鉛直断面の平均的な形状》から決定している。

これに対し、実験 $D$ は、福岡市の中心的市街地 $500 \mathrm{~m}$ 四方を再 現したもので、用途地域は商業、法定容積率は 600〜800\%に指定 されている。対象地域の実際の風向を考虑して、2 通りの風向に つて測定を行っている。対象とした街区は、比較的大きなオ一 プンスペースが散在し、街路方位と風向は一致していないという

\section{特徵を有する。}

模型の縮率は、実験 $A \sim D$ のいずれも 1/430 である。また、測定点 を模型周囲に 3 次元メッシュ状に配置し、特に気流の変化が激しい模 型高さ以下の領域については、模型上空に比べて測定点を密に配置し ている。

実験 $C$ の 3 ケース及び実験 $D$ における粗度表面積密度 $a_{x i}$ 及び粗度 体積密度 $\rho_{r}$ の鉛直分布を図 3 に示す。市街地模型の実験 $D$ は、床面付 近から上空へ徐々に建物が疎になっている様子が分かる。

風洞内模型配置の概要を図 4 に示寸。実験 $A, B$ 及び $C$ にいては、 境界層の発達を考慮して、測定対象エリアの上流側に約 $1.5 \mathrm{~m}$ にわた り測定対象とする模型配列と同じパターンを設置している。実験 $D に$ つては、模型配列の風上側と風下側に、市街地模型と同じ平均建物 密度となるように、直方体模型を整形配列している。

\section{表 1 キャノピーモデルの基砣式}

$$
\begin{aligned}
& \frac{1}{G} \frac{\partial G\left\langle\overline{u_{i}}\right\rangle}{\partial x_{i}}=0 \ldots(1) \\
& \frac{\partial\left\langle\overline{u_{i}}\right\rangle}{\partial t}+\frac{1}{G} \cdot \frac{\partial}{\partial x_{k}} G\left\langle\overline{u_{i}}\right\rangle\left\langle\bar{u}_{k}\right\rangle=-\frac{1}{\rho} \frac{\partial\langle\bar{p}\rangle}{\partial x_{i}}+\frac{1}{G} \frac{\partial}{\partial x_{k}}\left(G v_{t} \frac{\partial\left\langle\overline{u_{i}}\right\rangle}{\partial x_{k}}\right) \\
& -\beta g\left(\left\langle\overline{\theta_{v}}\right\rangle-\theta_{w}\right)-\varepsilon_{k_{1}} \Omega_{k} \overline{u_{1}}-F_{s} \ldots(2) \\
& \frac{\partial\langle\bar{\theta}\rangle}{\partial t}+\frac{1}{G} \frac{\partial}{\partial x_{k}} G\left\langle\overline{u_{k}}\right\rangle\langle\bar{\theta}\rangle=\frac{1}{G} \frac{\partial}{\partial x_{k}}\left(G \frac{v_{t}}{P_{n}} \frac{\partial\langle\bar{\theta}\rangle}{\partial x_{k}}\right)+\frac{\left\langle\overline{H_{a}}\right\rangle+\left\langle\overline{H_{s}}\right\rangle}{G C_{p} \rho} . \\
& \frac{\partial\langle\bar{q}\rangle}{\partial t}+\frac{1}{G} \frac{\partial}{\partial x_{k}} G\left\langle\overline{u_{k}}\right\rangle\langle\bar{q}\rangle=\frac{1}{G} \frac{\partial}{\partial x_{k}}\left(G \frac{v_{1}}{P_{n}} \frac{\partial\langle\bar{q}\rangle}{\partial x_{k}}\right)+\frac{\left\langle\overline{Q_{a}}\right\rangle+\left\langle\overline{Q_{2}}\right\rangle}{G \rho} \ldots \\
& \frac{\partial k}{\partial t}+\frac{1}{G} \frac{\partial}{\partial x_{k}} G\left(\overline{u_{k}}\right\rangle k=\frac{1}{G} \frac{\partial}{\partial x_{k}}\left(G \frac{v_{1}}{\sigma_{k}} \frac{\partial k}{\partial x_{k}}\right)+P_{k}-\varepsilon+G_{k}+F_{k} \ldots(5) \\
& \frac{\partial \varepsilon}{\partial t}+\frac{1}{G} \frac{\partial}{\partial x_{k}} G\left(\overline{u_{k}}\right) \varepsilon=\frac{1}{G} \frac{\partial}{\partial x_{k}}\left(G \frac{v_{1}}{\sigma_{E}} \frac{\partial \varepsilon}{\partial x_{k}}\right)+\frac{\varepsilon}{k}\left(C_{1 E} P_{k}-C_{2 E} \varepsilon+C_{3 E} G_{k}+F_{E}\right) \ldots(6) \\
& P_{k}=v_{1}\left(\frac{\partial\left\langle\overline{u_{i}}\right\rangle}{\partial x_{k}}+\frac{\partial\left\langle\bar{u}_{k}\right\rangle}{\partial x_{i}}\right) \frac{\partial\left\langle\bar{u}_{i}\right\rangle}{\partial x_{k}} \ldots . . .(7) \quad G_{k}=g_{k} \beta \frac{v_{t}}{P_{n}} \frac{\partial\left\langle\bar{\theta}_{v}\right\rangle}{\partial x_{k}} \ldots . .(8) \\
& F_{x i}=\frac{1}{2} a_{x i} C_{f(}\left(\left\langle\overline{u_{k}}\right\rangle^{2}\right)^{0.5} \overline{u_{i}} \ldots(9) \\
& F_{v}=\frac{1}{2} a_{x i} C_{f i}\left(\left\langle\overline{u_{k}}\right\rangle^{2}\right)^{3 / 2} \ldots(10) \quad F_{E}=C_{k E} k^{2 / 3} / L \ldots(11)
\end{aligned}
$$

$x_{i}$ 座僄 $u_{i}: x i$ 方向の風速成分, $t$ 時間， $\rho$ 空気の密度 $p$ :圧力, $\theta, \theta_{m} \theta_{w}$ 温位仮温位平

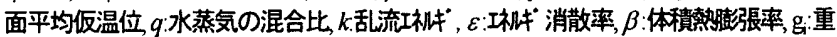

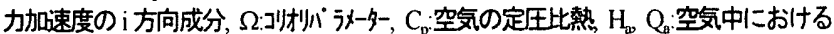
熱 水蒸気の発生量, $\mathrm{H}_{\mathrm{k}} \mathrm{Q} \mathrm{Q}$ : 分子拡散による $\mathrm{x}_{\mathrm{k}}$ 方向の熱 水蒸気のフラ $\% 久, L$ : 乱れの長

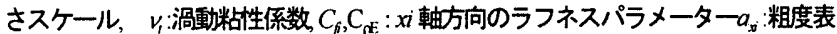
面積密度, $G$ :単位空間当たり流体体積 $\langle\bar{f}>: f$ 単位流体体積当たりアンサンブ 儿平均, $C_{I E}=1.44, C_{2 E}=1.92, C_{D}=0.09, \sigma_{k}=1.00, \sigma_{\mathrm{E}}=1.30$

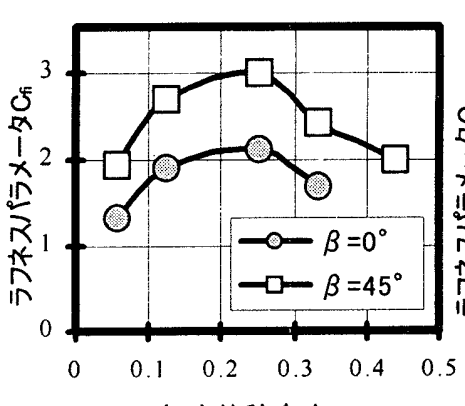

粗度体積密度 $\rho_{\mathrm{r}}$

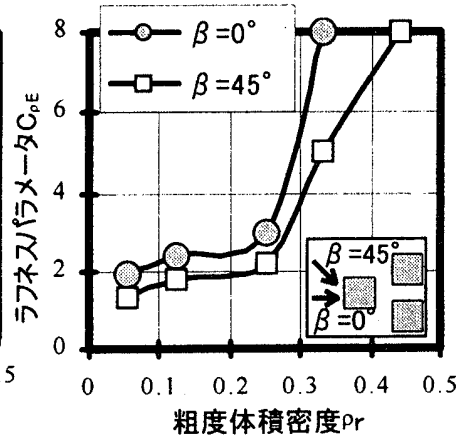

粗度体積密度 $\mathrm{Pr}$
图 1 ラフネスパラメータと粗度体䅡密度の関係(文献 6 より引用) 


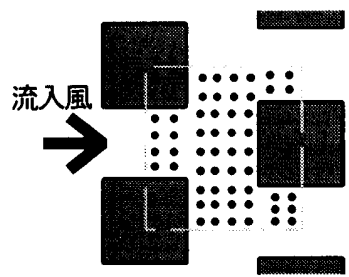

(a) 実跧 $A$ (ケース $A-S 2)$

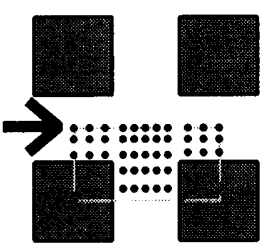

(b) 実験 B (ケース B-N2)

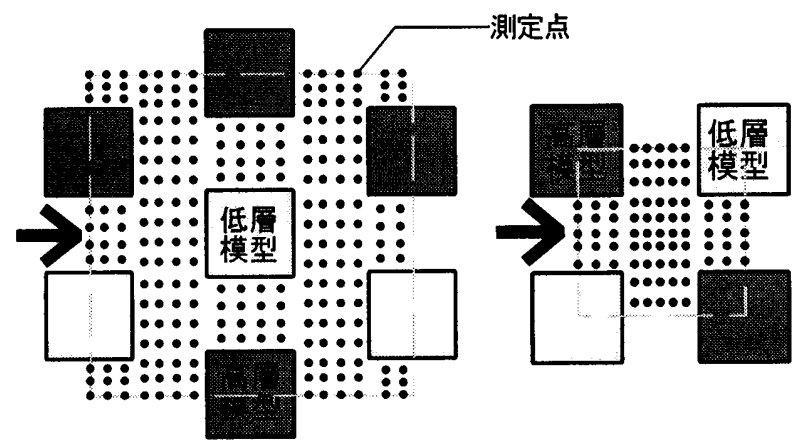

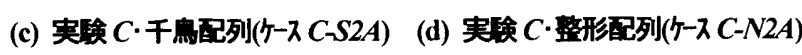

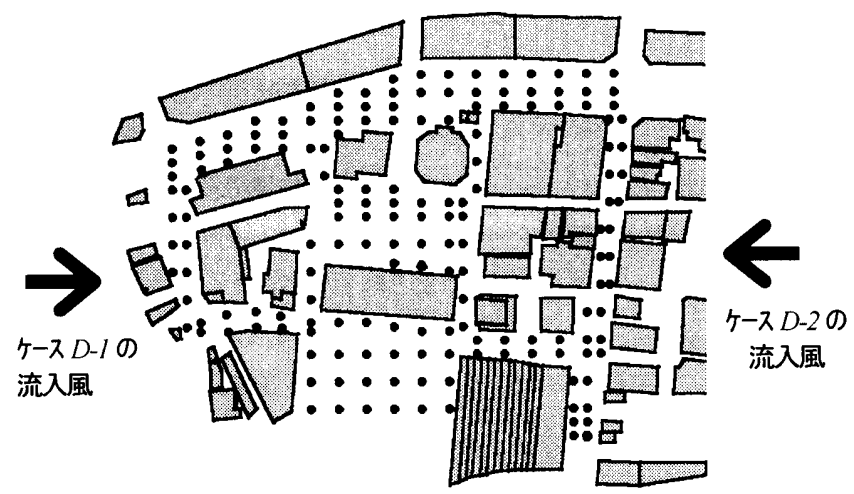

(e) 実験 $D$

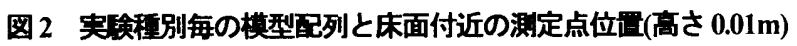
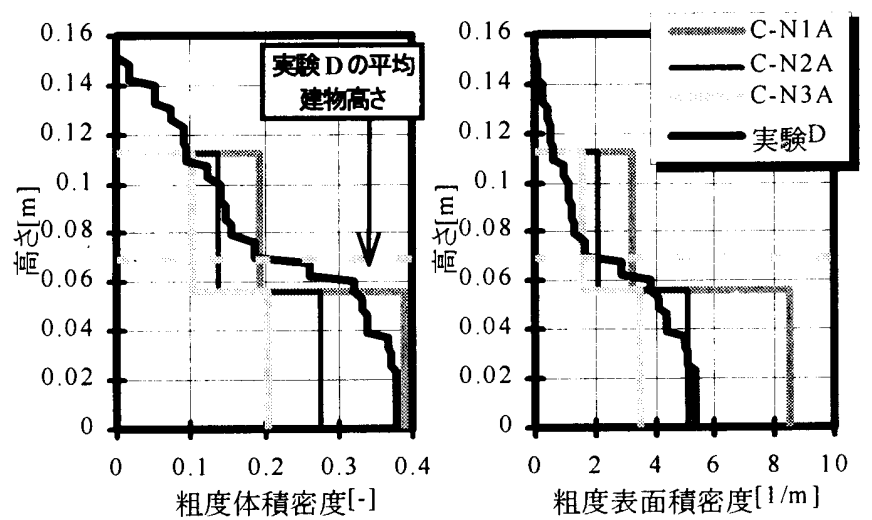

図 3 実検 $C, D$ の粗度体稜密度及び粗度表面档密度の铅直分布

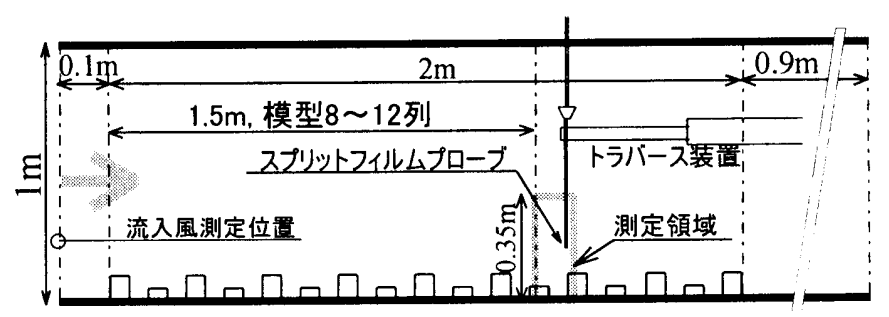

(a) 実験 $A, B, C$

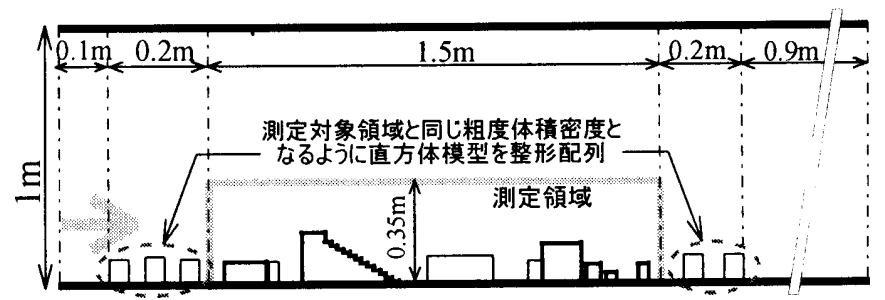

(b) 実験 $D$

图 4 風洞内の模型列状況

表 2 模型配列条件の概要

\begin{tabular}{|c|c|c|c|c|c|c|c|c|c|c|c|}
\hline \multirow{2}{*}{ 実験種別 } & \multirow{2}{*}{ 特徴 } & \multirow{2}{*}{ ケース名 } & \multirow{2}{*}{$\begin{array}{l}\text { 模型 } \\
\text { 高さ }\end{array}$} & \multirow{2}{*}{ 配置 } & \multirow{2}{*}{$W / h_{l}$} & \multirow{2}{*}{$W^{\prime} h_{2}$} & \multicolumn{2}{|c|}{ 粗度体積密度 $\rho_{r} \quad[-]$} & \multicolumn{2}{|c|}{ 粗度表面積密度 $a[1 / \mathrm{m}]$} & \multirow{2}{*}{$\begin{array}{l}\text { 測定 } \\
\text { 点数 }\end{array}$} \\
\hline & & & & & & & $\mathrm{z}<h_{1}$ & $h_{1}<\mathrm{Z}<h_{2}$ & $\mathrm{z}<h_{l}$ & $h_{1}<\mathrm{z}<h_{2}$ & \\
\hline \multirow{3}{*}{$A$} & \multirow{3}{*}{$\begin{array}{c}\text { 同一サイズ直方体模型 } \\
\text { の千鳥配列 }\end{array}$} & $A-S l$ & \multirow{3}{*}{$h_{l}=1 \mathrm{H}$} & \multirow{3}{*}{ 千鳥 } & 0.8 & & 0.391 & & 8.55 & & 244 \\
\hline & & $A-S 2$ & & & 1.2 & & 0.277 & & 5.12 & & 412 \\
\hline & & $A-S 3$ & & & 1.6 & & 0.207 & & 3.47 & & 412 \\
\hline \multirow{3}{*}{$B$} & \multirow{3}{*}{$\begin{array}{c}\text { 同一サイズ直方体模型 } \\
\text { の整形配列 }\end{array}$} & $B-N I$ & \multirow{3}{*}{$h_{l}=1 \mathrm{H}$} & \multirow{3}{*}{ 整形 } & 0.8 & & 0.391 & & 8.55 & & 244 \\
\hline & & $B-N 2$ & & & 1.2 & & 0.277 & & 5.12 & & 412 \\
\hline & & $B-N 3$ & & & 1.6 & & 0.207 & & 3.47 & & 412 \\
\hline \multirow{8}{*}{ C } & \multirow{8}{*}{$\begin{array}{c}\text { 高さの異なる } \\
2 \text { 種類の直方体模型の } \\
\text { 整形配列·千咀配列 }\end{array}$} & $C-N I A$ & \multirow{4}{*}{$\begin{array}{l}h_{1}=1 \mathrm{H} \\
h_{2}=2 \mathrm{H}\end{array}$} & \multirow{3}{*}{ 整形 } & 0.8 & 1.47 & 0.391 & 0.195 & 8.55 & 3.24 & 542 \\
\hline & & $C-N 2 A$ & & & 1.2 & 1.87 & 0.277 & 0.139 & 5.11 & 2.14 & 1088 \\
\hline & & $C-N 3 A$ & & & 1.6 & 2.27 & 0.207 & 0.103 & 3.47 & 1.54 & 892 \\
\hline & & $C-S 2 A$ & & 千鳥 & 1.2 & 1.87 & 0.277 & 0.139 & 5.11 & 2.14 & 2444 \\
\hline & & $C-N I B$ & \multirow{2}{*}{$\begin{array}{c}h_{1}=1 \mathrm{H} \\
h_{2}=1.5 \mathrm{H}\end{array}$} & \multirow{2}{*}{ 整形 } & 0.8 & 1.95 & 0.391 & 0.195 & 8.55 & 3.24 & 538 \\
\hline & & $C-N 3 B$ & & & 1.6 & 3.02 & 0.207 & 0.103 & 3.47 & 1.54 & 846 \\
\hline & & $C-N I C$ & \multirow{2}{*}{$\begin{array}{c}h_{1}=0.5 \mathrm{H} \\
h_{2}=1 \mathrm{H}\end{array}$} & \multirow[b]{2}{*}{ 整形 } & 1.6 & 2.93 & 0.391 & 0.195 & 8.55 & 3.24 & 470 \\
\hline & & $C-N 3 C$ & & & 3.2 & 4.53 & 0.207 & 0.103 & 3.47 & 1.54 & 706 \\
\hline \multirow{2}{*}{$D$} & オープンスペースを有す & $D-1$ & \multirow{2}{*}{\multicolumn{2}{|c|}{ 実在 }} & 脑の & 市街地 & 万る天神 & )を再現 & 一縮小模王 & 吏用。 & 1495 \\
\hline & る実在市街地模型 & $D-2$ & & & & & & ている。 & & & \\
\hline
\end{tabular}

$W$ :模型間隔, $H$ :標準模型高さ $56.3 \mathrm{~mm} \quad$ 模型基準サイス $B 75 \times B 75 \times H 56.3 \mathrm{~mm}, h_{i}:$ 低層模型の高さ, $h_{2}:$ 高層模型の高さ, $W^{\prime}:$ 高層模型の間隔 $\left(W^{\prime}=2 W+B\right)$ 

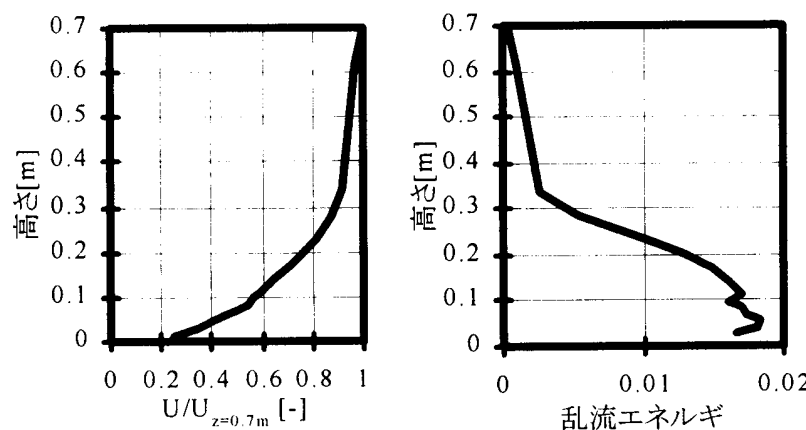

図 5 接近流の平均風速と乱流エネルギの鉛直分布

\section{3-2 㵋定機器}

模型周辺風速は、スプリットフィルムプローブ（日本科学工業製 Model 1288）を用いて主流方向 $\mathrm{x}$ 成分について測定を行う。プローブ の出力は定温度型熱線流速計の CTA ユニット (日本科学工業製 Model 1101）、リニアライザ（日本科学工業製 Model 1103）を介して $\mathrm{AD}$ 変 換器に取り込まれる。測定時間間隔 $1 \mathrm{~ms}$ で約 30 秒間の)全 30,720 個の 平均值を解析に用いる。

\section{3-3 接近流}

模型高さに比較して十分厚く乱れも大きい乱流境界層を形成するた め、模型群の上流にスパイヤ、乱流格子、ラフネスを設置している。

尚、基準風速 $U_{z-07 m}$ を $7 \mathrm{~m} / \mathrm{s}$ として、実験を行っている。

接近流の平均風速と乱流エネルギの鈆直分布を図 5 に示寸。尚、風 速および乱流エネルギは高さ $0.7 \mathrm{~m}$ における風速で無次元化して表示 している注22

\section{3-4 キャノピーモデルによる乱流数値計算の概要}

前述の表 1 に示す基礎式に基づき 2 次元標準 $k$-๕モデルにキャノピー モデルを組み込んだ乱流数值計算を行い、風洞模型実験の再現を行う。 格子分割、境界条件等の概要を表 3 に示す。キャノピーモデル中に含 まれるラフネスパラメータ $C_{f} C_{\rho \notin}$ は土丸山による同定結果から粗度体積 密度の関数として定義するため、同じ粗度体積密度の条件下で、平面 配置が異なる場合の風速プロフィルの違いは表現されない。
表 3 キャノピーモデルによる乱流数值計算の概要

\begin{tabular}{|c|c|}
\hline 計算領域 & $\begin{array}{l}\text { 主流方向 X3m×䯩さ方向 Y } 1.5 \mathrm{~m} \\
\text { (図 } 4 \text { に示す風洞内を2 次元で表現) }\end{array}$ \\
\hline メッシュ分割 & 不等間隔 $(X 100$ mesh $\times$ Y 50 mesh $=5000$ mesh $)$ \\
\hline 基礎式 & 乱流 $k$-えこキャノピーモデルを組み込んだ表 2 注1) \\
\hline 流入境界条件 & 実験データ(図 5) \\
\hline 流出境界条件 & $u_{s} k, \varepsilon$ の主流方向勾配ゼロ \\
\hline 床·天井境界条件 & 対数則に基づく壁関数で定義 \\
\hline $\begin{array}{l}\text { ラフネス } \\
\text { パラメータ }\end{array}$ & $\begin{array}{l}\text { 丸山による図 } 1 \text { における } \beta=0^{\circ} \text { の值を用い、各格 } \\
\text { 子における粗度体積密度の関数として定義 }\end{array}$ \\
\hline
\end{tabular}

\section{4. キャノピーモデルによる数值計算と風洞実験の比較}

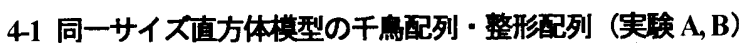

各高さの実験值を面積重み平均して算出した空間平均風速の鉛直分 布とキャノピーモデルによる計算值の比較を行う。同一サイズ直方体 の千鳥配列（実験 A）及ひ整形配列（実験 B）の結果を、粗度体積密 度で分類して図 6(a) ( c ) に示す。

キャノピー上空では、いずれのケースも直線上にプロットが並ぶ対 数分布を示し、同じ粗度体積密度の条件下では、千鳥配列と整形配列 の実験值はほぼ同じ值となっている。また、キャノピーモデルによる 計算値は実験值とほぼ一致している。

キャノピー高さ以下については、同じ粗度体積密度の場合、風上か らみた粗度の立面積が大きい千鳥配列の実験值か整形配列の実験值に 比べさな風速となっている。特に、最も粗度体積密度が大きいケー ス A-S1 は床面付近の風速がマイナスの值を示し、逆流が卓越してい る事が分かる。キャノピーモデルによる計算值は、ケース A-S2, B-N2 のみやや実験值との差が大きくなっているが、概小実験值とほほ類似 O)傾向を示し、千鳥配列（実験 A）と整形配列（実験 B）の)中間O值 を示している。

\section{$4-2$ 高さの異なる直方体模型の千鳥,整形配列（実酫 C）}

図7に高さの異なる 2 種類の直方体模型を交互に配列した場合の風 速プロフィルを示す。高層模型の上空では、計算値と実験値はいずれ も対数分布を示し両者は良く一致している。また、高層模型高さ以下 の領域について、計算值と実験値は類似の傾向を示している。これ

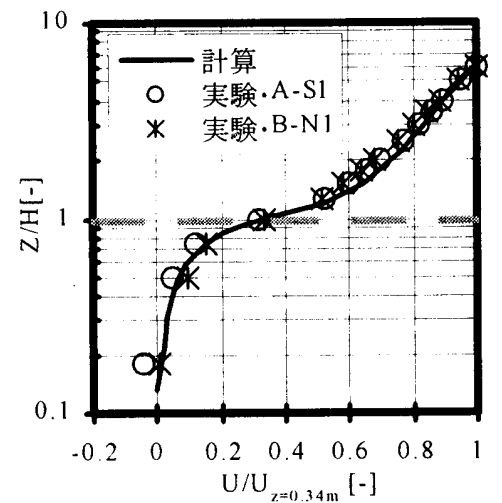

(a) 千鳥 $A-S 1$, 整形 $B-N 1\left(\rho_{r}=0.391\right)$

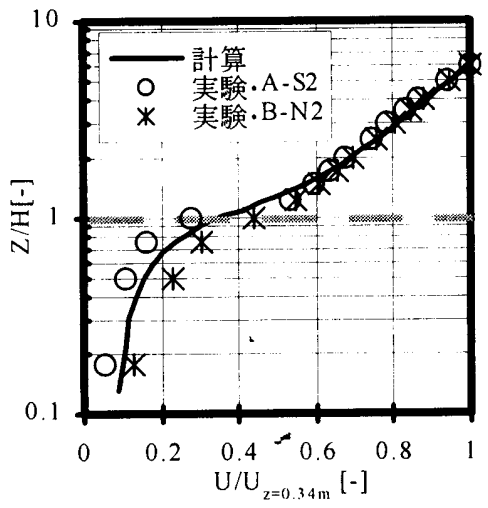

(b) 千禹 $A_{-} S 2$, 整形 $B-N 2\left(\rho_{r}=0.277\right)$

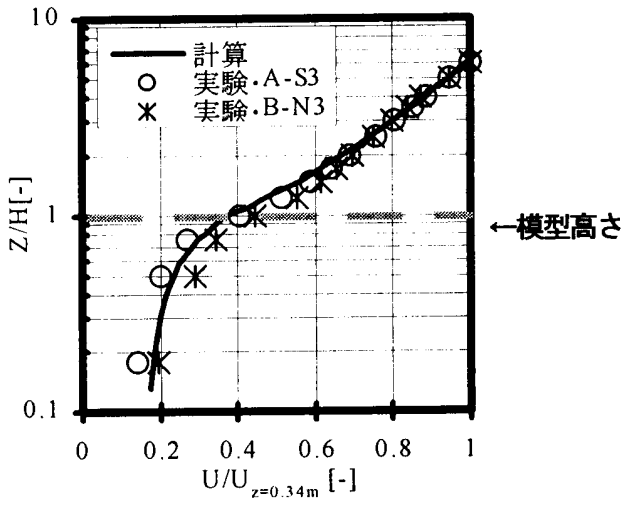

(c)千重 $A-S 3$, 整形 $B-N 3\left(\rho_{r}=0.207\right)$

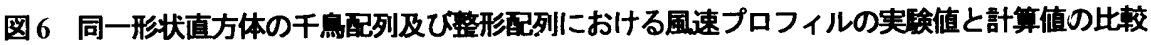




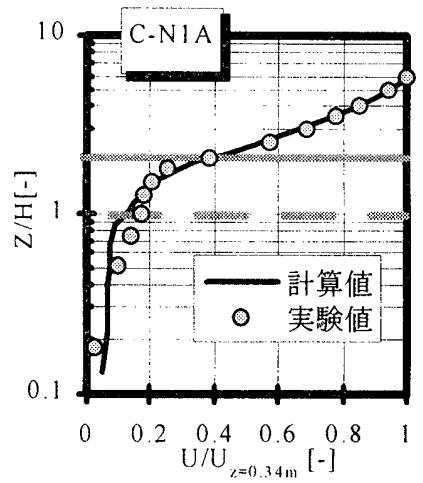

(a) ケース $C-N 1 A$

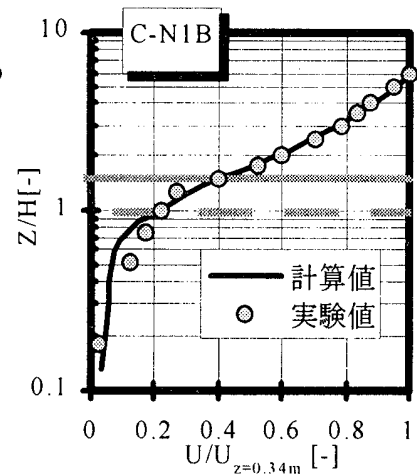

(b) ケース $C-N 1 B$

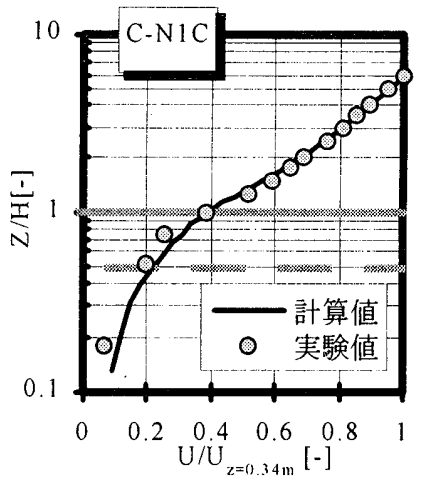

(c) ケース C-NIC

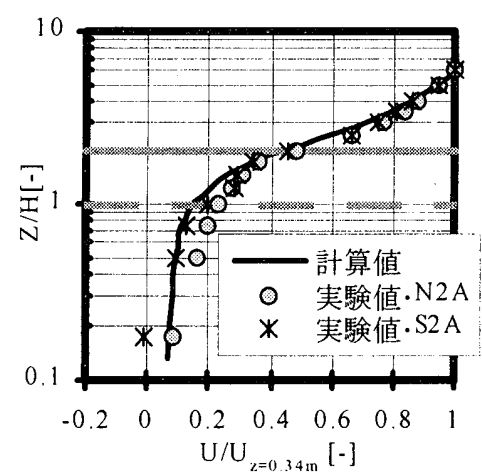

(d) ケース C-N2A,C-S2A

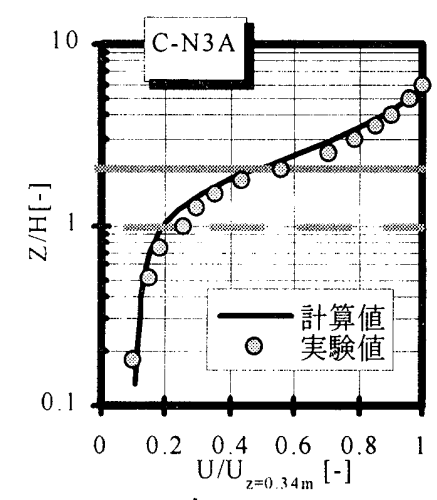

(e) ケース C-N3A

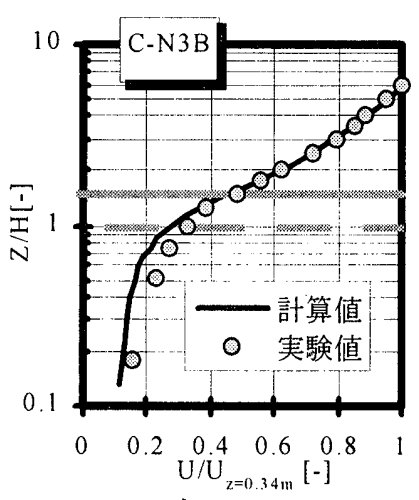

(f) ケース C-N3B

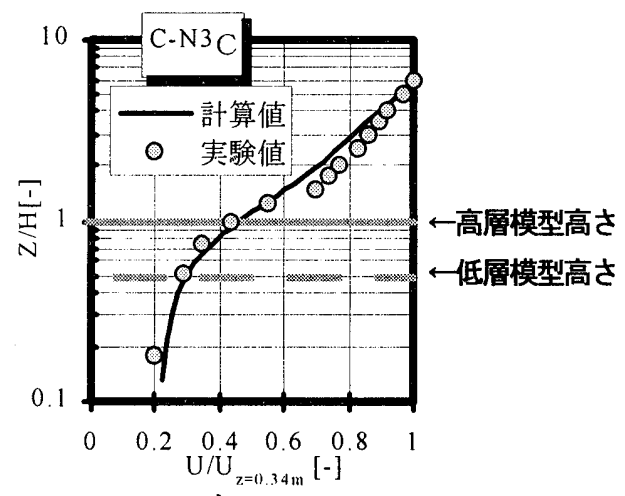

(g) ケース C-N3C

図 7 高さの異なる 2 種類の模型による整形配列及び千鳥配列（実験C）の風速プロフィルの実験値と計算値の比較

らの結果から、用いたラフネスパラメータが、高さの異なる直方体模 型配列時に顸いても適用できると言える。

\section{$4-3$ 実在市街地の縮小模型（実倹 D）}

福岡市の中心的商業地区を再現した縮小模型の風速プロフィルを図 8 に示す。尚、綐軸はエリア内の平均建物高さで無次元化を行ってい る。風向の異なる 2 条件のいずれも、平均建物高さ付近で実験值と計 算値はやや異なる值を示しているが、床面付近においては両者は極め て近い傾向を示している。

\section{5. 結論}

キャノピーモデルを都市の風通し評価のツールとして位置づけ、以 下の検討を行った。

1) 同一サイ、ス直方体模型の千鳥配列及ひ整形配列、高さの異なる 2 種 類の直方体模型による千鳥・整形配列、実在市街地の縮小模型を用 いた 4 種類計 16 通りの風洞実験を行い、模型周辺の 3 次元的気流 分布の測定值から空間平均風速 0 鉛直分布を求めた。

2) 風洞実験を再現したキャノピーモデルによる数值計算を行い、実験 值との比較を行った。尚、キャノピーモデル中のラフネスパラメー 夕は、丸山の示した立方体千鳥配列の值を用い、粗度体積密度の関 数として定義した。

その結果、キャノピーモデルによる計算値と実験值は、いずれのケ 一スも概ね一致する事が確認された。

以上により、粗度体積密度の関数として表現されたラフネスパラメ 一ターを用いることで、キャノピーモデルは、市街地上空のみならず、 キャノピー層内、地表面付近における街区の平均風速の予測ツールと

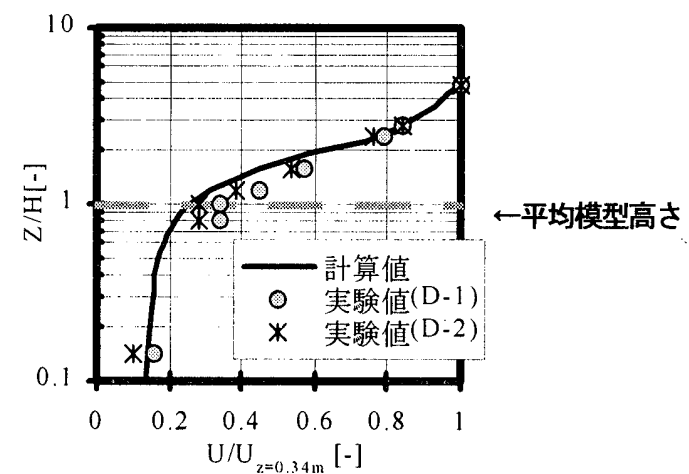

図 8 市街地模型(実験 D)にたける風速プロ ロ价の実験値と計算値の比較 なりうると考えられる。

今後は、筆者らが別途開発を進めている都市高温化予測シミュレー ター「建築一都市一土壌連成系モデル AUSSSM(Architecture-UrbanSoil Simultaneous Simulation Model)」の大気側サブモデルにキャノピー モデルを組み込み、都市高温化の定量的要因解析を行う予定である。

注記

注1) 本稿では中立時についてのみ検討を行っているため、数値計算 において表 2 の式(3)及び式(4)は使われていない。

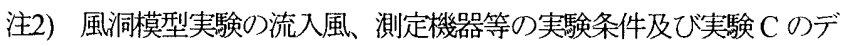
一夕は拙稿 ${ }^{10}$ と同一のものである。併せてご高覧頂きたい。 


\section{謝辞}

風洞模型実験は、当時九州大学大学院生森竹千景氏、大原健志氏、当 時近畿大学 4 年生江副紀子氏によって行われた。本研究の一部は文部 省科学研究費 - 地域連携推進研究「地域熱供給計画支援都市熱環境シ ミュレーターの開発」(代表片山忠久,課題番号 11792017)に拠る。ここ に記して感謝の意を表する

\section{【参考文献】}

1) 例えば、村上周三,日比一喜,持田灯，Large Eddy Simulation による街 区周辺の乱流場の 3 次元解析 (その1) 隣棟間隔の変化が流れ場に 与える影響と風洞実験 0 比較, 日本建築学会計画系論文報告集, No.412, pp.1-10, 1990.6

2）例えば、森川泰成工藤圭子，小野浩志西村正和，市街地における温 熱環境の予測・評価手法の検討-Rapid Prototype 技術の適用一，日 本建築学会学術講演梗概集(関東)1997 年9月,pp.869-872, 1997.9

3) 鵜野伊津志,植田洋匡若松伸司,中村晃, 乱流モデルによる夜間都市 境界層の形成機構の検討, 衛生工学研究論文集, Vol.24, pp.125-137, 1988
4) 平岡久司,丸山敬,中村泰人,桂順治, 植物群落内およひ都市キャノピ 一内の乱流モデルに関寸る研究(その 1)乱流モデルの作成，日本建 築学会計画系論文集 No.406,pp.1-9, 1989.12

5) 丸山敬, 立方体粗度ブロックの配列形状の違いによる抗力の変化 について,日本風工学会誌,No.49,p.15-24, 1991.11

6) 丸山敬, 粗面上に発達する乱流境界層の数值シミュレーション(そ の2:市街地のように粗度形状が複雑な場合),日本風工学会誌 No.47, p.81-82, 1991.4

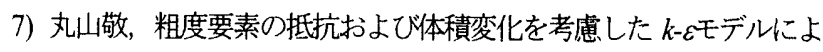
る乱流境界層の数值計算, 日本建築学会構造系論文集 No.404, pp.75-81, 1989.10

8) ヴタンカ,足永靖信,浅枝隆，都市大気境界層の乱流モデリング 都 市建築計画における都市気候予測システムの開発その 1 , 日本建築 学会大会計画系論文集 No.536,pp.95-100,2000.10

9) 早稲田大学尾島研究室資料 : 都市の断面形態比較, 1994.7

10)萩島理,片山忠久，谷本潤森竹干景,江副紀子，高さの異なる直方体模 型群の周辺気流特性に関する風洞実験, 日本建築学会計画系論文集 No.538, pp.15-21, 2000.12 